\title{
The Virtual Community of Practice for School Principals: A Professional Development Method
}

\author{
Monique Lambert, Yamina Bouchamma \\ Department of Educational Foundations and Practices, Faculty of Education, Université Laval, Québec, QC, Canada \\ Email: monique.lambert.2@ulaval.ca,yamina.bouchamma@fse.ulaval.ca
}

How to cite this paper: Lambert, M., \& Bouchamma, Y. (2021). The Virtual Community of Practice for School Principals: A Professional Development Method. Creative Education, 12, 422-440. https://doi.org/10.4236/ce.2021.122030

Received: January 17, 2021

Accepted: February 22, 2021

Published: February 25, 2021

Copyright $\odot 2021$ by author(s) and Scientific Research Publishing Inc. This work is licensed under the Creative Commons Attribution International License (CC BY 4.0).

http://creativecommons.org/licenses/by/4.0/

(c) (i) Open Access

\begin{abstract}
In an education system that is constantly evolving, school principals play a pivotal role, hence the importance of continuing their professional development in order to acquire the necessary competencies to perform effectively throughout their professional careers. This article examines the characteristics of a community of practice ( $\mathrm{CoP})$ as a professional development approach with a group of school principals $(\mathrm{N}=10)$ who participated in a virtual CoP for one year. The corpus from the semi-structured interviews was analysed by considering the four components of Wenger's (2005) social theory of learning, namely, meaning, practice, community, and identity. Our results also showed the levers of this support method during its implementation.
\end{abstract}

\section{Keywords}

Virtual Community of Practice, CoP, Professional Development of School Principals, School Management Competencies

\section{Introduction}

\subsection{The Competencies of School Principals}

With education systems constantly changing, school principals are inevitably at the heart of many reforms implemented in their institutions (Murakami, Tornsen, \& Pollock, 2014; NPBEA, 2015; Pont, Nusche, \& Moorman, 2008). As a result, school management has become increasingly complex, requiring that these education leaders hone their knowledge base and expand their expertise to address the challenges (Ingvarson, Anderson, Gronn, \& Jackson, 2006; Mulford, 2003; Perrenoud, 2002). Therefore, more than ever, school principals must possess the necessary competencies to meet the standards of quality associated with their position, particularly considering the favourable impact principals 
are known to have on their school's environment (Barber, Whelan, \& Clark, 2010; Bisaillon, Inchauspé, Massé, Miron, Morin, \& Sauvageau, 2009; Darling-Hammond, Meyerson, LaPointe, \& Orr, 2010; Pont et al., 2008; UNESCO, 2006).

To ensure that school principals have the appropriate professional skills to effectively perform their duties, basic training in school management is now a standard required to practice in many countries (Pont et al., 2008; UNESCO, 2006). Although this initial training helps principals to initiate the acquisition of these specific competencies, it does not suffice to support the development of every skill required for effective educational management (Legendre, 2007).

\subsection{Professional Development}

Professional development (PD) is an excellent way to upgrade or enhance the knowledge and competence necessary for successful school management at each stage of the principal's career (Paquay, Nieuwenhoven, \& Wouters, 2010; Pont et al., 2008). Logically, this process extends throughout the course of the school leader's professional trajectory and is necessary to ensure and support effective actions relative to this important position of influence (Legendre, 2007; Pont et al., 2008; Salazar, 2007; Barber et al., 2010). Specifically, the activities associated with their PD must be continuous, in context, and without interruption, based on their existing competencies and level of professional experience (Peterson, in Davis, Darling-Hammond, LaPointe, \& Meyerson, 2005).

While it is imperative that the professional development of school principals be recognised and supported, the manner in which this PD is currently dispensed is far from structured, as is evidenced by the wide range of training models (Cattonar, Lessard, Blais, Larose, Riopel, Tardif, \& Bourque, 2007).

\section{Types of Professional Development Training}

Three types of training methods are possible to acquire the required competencies during the PD: formal training, supported by the education system and concluding with a diploma; non-formal training through such planned activities as training workshops or mentoring; and finally, informal training experienced on a volunteer basis through other types of activities such as personal research or networking within the system (Coombs, Prosser, \& Ahmed, 1973; Daele, 2004; Isabelle, Meunier, \& Gélinas Proulx, 2016; Richter, Kunter, Klusmann, Lüdtke, \& Baumert, 2011; Werquin, 2010).

School principals generally obtain PD through non-formal or informal training in the form of workshops, seminars, participation in support networks, securing a resource mentor, or simply through personal research (Cattonar et al., 2007; Isabelle et al., 2016).

However, studies show that support for school principals appears to be concentrated in the first five years of their career (Cattonar et al., 2007; Isabelle et al., 2016). The latter observation brought us to examine the effect of the guidance and support offered to principals regardless of the school principals' back- 
grounds. Considering the strategic role principals have been shown to play in improving school effectiveness (Barber et al., 2010; Salazar, 2007), effective PD must be sustained throughout the latter's career (Ingvarson et al., 2006; Pont et al., 2008). Furthermore, professional continuing development must take into account the individual needs of these school leaders (Peterson, in Davis et al., 2005; Pont et al., 2008). Communities of practice (CoP) address this aspect.

\subsection{Professional Development in the Community of Practice}

The CoP, an informal training model, can indeed be a motor for professional development (CTREQ, 2013) because it becomes an opportunity for the school principals to share its professional practices or experiences in co-construction with colleagues (Savoie-Zajc, 2010). The prime directive is to provide an environment for constructive dialogue between individuals who share a common interest in developing specific capabilities; in this regard, networking to stay informed regarding work-related issues represents an excellent opportunity for individual professional growth (Lesser \& Storck, 2001; Wenger, McDermott, \& Snyder, 2002). Moreover, when combined with technology, the virtual CoP becomes a new direction for PD (Wenger, 2001).

Few studies have been devoted to supporting school principals in a process of professional development of their competencies and these have focused only on new school principals (Isabelle \& Labelle, 2017, Isabelle et al., 2016; Merriam, Caffarella, \& Baumgartner, 2009). In our research, we are interested about professional development for all school principals, regardless of their experience, which is new. In addition, it should be noted that in the previous studies, the CoP does not appear to have been studied as a method of professional development for principals, ever less the virtual CoP.

\subsection{Research Objective}

After one year of meeting, we examined how the participation of school principals in a virtual $\mathrm{CoP}$ could ensure the continuing development of the required school management competencies by analysing the main characteristics of this supervision model based on the four aspects laid forth in Wenger's (2005) social theory of learning, namely meaning, practice, community and identity, while identifying the levers associated with the establishment of a $\mathrm{CoP}$ in professional development.

\section{Conceptual Framework}

Professional development and the $\mathrm{CoP}$ are the two concepts supporting this study. Table 1 presents several elements characterising the similarities and differences between PD and the CoP. While participation in PD activities and the $\mathrm{CoP}$ is voluntary, $\mathrm{PD}$ is a broader concept than that of the CoP, as different types of training formats are possible. The CoP, on the other hand, is a variation of professional development characterised by its informal aspect. 
Table 1. Comparative analysis of professional development and the community of practice.

\begin{tabular}{|c|c|c|}
\hline & Professional Development & Community of Practice \\
\hline Definition & $\begin{array}{l}\text { - Improves knowledge and skills that lead to changes in } \\
\text { professional practice (Brodeur, Deaudelin, \& Bru, 2005; } \\
\text { Paquay et al., 2010). }\end{array}$ & $\begin{array}{l}\text { - Provides learning opportunities for participants thanks } \\
\text { to their active participation in work-related practices } \\
\text { (Lave \& Wenger, 1991). }\end{array}$ \\
\hline Objectives & $\begin{array}{l}\text { - Develop new competencies (Barbier \& Galatanu, 2004). } \\
\text { Ensure a rapid adaptation to changing professional contexts } \\
\text { because the person reflects on their practice (Wittorski, } \\
\text { 2007). }\end{array}$ & $\begin{array}{l}\text { Share information, ideas, advice; discuss problems, } \\
\text { experiences, tools, models, new practices, contexts, } \\
\text { professional aspirations, and needs; learn from others } \\
\text { who share the same interests (Mottier-Lopez, 2007; } \\
\text { Wenger, 1998, 2005; Wenger et al., 2002). }\end{array}$ \\
\hline Mode of operation & $\begin{array}{l}\text { - May be formal training (school or training centre), } \\
\text { non-formal training (organised non-evaluated activities), or } \\
\text { informal training (unorganized, unstructured, or } \\
\text { unintentional learning) (OCDE, 2007). } \\
\text { - Improves the skills required to exercise a profession } \\
\text { (Bourdoncle, 1991; Nolan \& Hoover, 2008). } \\
\text { - Mobilises the skills required to deal effectively with work } \\
\text { situations (Paquay et al., 2010). }\end{array}$ & $\begin{array}{l}\text { - Informal training } \\
\text { - Group meetings based on the desire to learn together } \\
\text { by relying on each other in a particular area of their } \\
\text { professional practice (Wenger, 1998). } \\
\text { - Discussion opportunities between the CoP members } \\
\text { are a source of enrichment that enables them to } \\
\text { discover and share a multitude of practices and new } \\
\text { perspectives to generate reflection with regard to } \\
\text { individual practices (Payette \& Champagne, 1997). }\end{array}$ \\
\hline Participation & $\begin{array}{l}\text { - A person cannot undertake a PD process unless they are } \\
\text { willing to do so voluntarily to develop competencies that will } \\
\text { be useful to them in their duties (Beckers, 2010; Guillemette } \\
\text { \& Savoie-Zajc, 2012; L'Hostie \& Boucher, 2004; Le Boterf, } \\
\text { 2007, 2008; Uwamariya \& Mukamurera, 2005). }\end{array}$ & $\begin{array}{l}\text { - Participation is voluntary. This is a long-term process, } \\
\text { usually with small groups of individuals. The members } \\
\text { share a common interest; they will share and learn } \\
\text { from each other (Wenger et al., 2002). }\end{array}$ \\
\hline Ideal situations & $\begin{array}{l}\text { - Pertain to the challenges to overcome, problems to solve, or } \\
\text { projects to undertake (Paquay et al., 2010). } \\
\text { - The PD must be continuous throughout the person's } \\
\text { professional career, as the issues constantly evolve (Brodeur } \\
\text { et al., 2005; Paquay et al., 2010). }\end{array}$ & $\begin{array}{l}\text { - Participants have the desire to discuss their issues, } \\
\text { experiences, tools, models, new practices or even better } \\
\text { ones (Wenger et al., 2002). } \\
\text { - The activities generate a need to reflect and to explore } \\
\text { new strategies for a given situation (Lesser \& Storck, } \\
\text { 2001; Wenger et al., 2002). }\end{array}$ \\
\hline
\end{tabular}

PD addresses the participants' personal needs, whereas the CoP focuses specifically on mutual support, long-term collaboration, and the dynamic involvement of its members, which is facilitated by the group's homogeneity; this allows for individual learning and growth. In other words, the CoP involves collective learning, where each member not only learns about themselves but also gathers information and knowledge on education issues with the help of the other members, which ultimately directs them toward constructive action (Wenger, 2005). However, more and more authors consider PD to be a process that not only provides preparatory training but also generates vital interactions between professional peers and personal reflection on work-related concerns (Day, 1999; Lieberman \& Miller, 2001).

CoP remains an opportunity for a group with common interests to share on a particular topic associated with their work functions, planning regular meetings to explore different possibilities to do, in a better way, through the exchanges between colleagues generated by the CoP (Wenger, 2005).

\section{Social Theory of Learning}

According to Wenger (2005), the CoP ensures learning through the participation 
of the people involved in the meetings, which allows for active collaboration among them by sharing their practices, thus giving meaning to the events so that each person builds his or her identity. New competencies can be developed in this way. He called this principle the social theory of learning.

$\mathrm{CoP}$ practices are based on the social theory of learning and its four basic components: meaning, practice, community and identity (Wenger, 2005) defined in this way (see Figure 1):

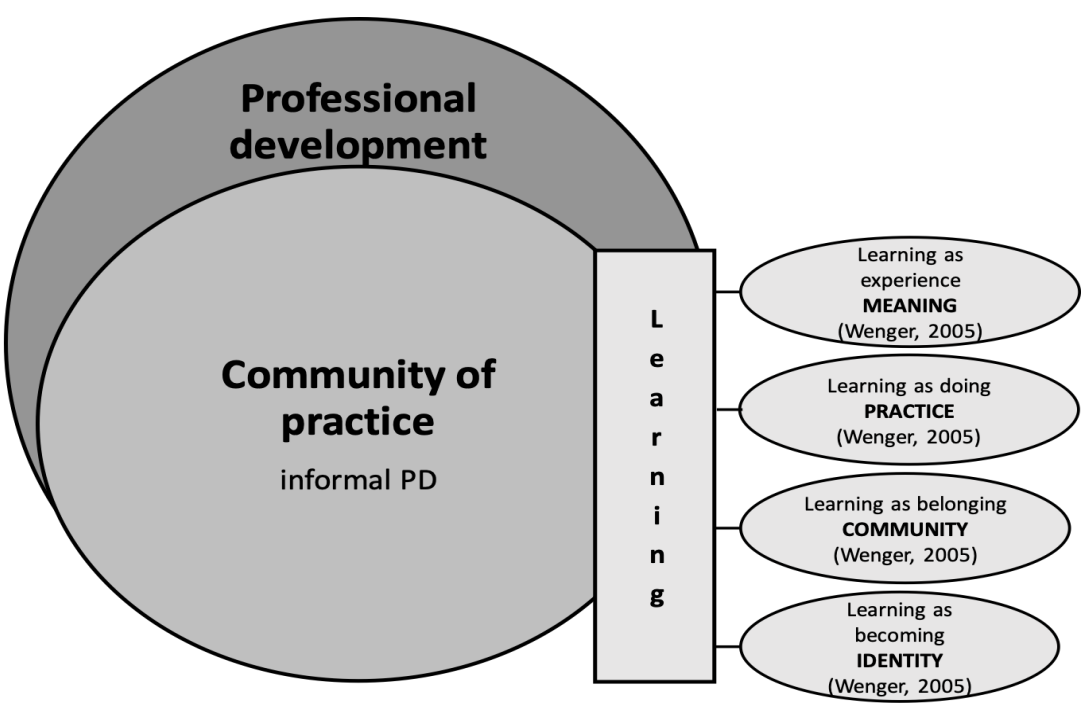

Figure 1. The CoP: An informal professional development model based on the social theory of learning (Wenger, 2005).

- Meaning: making sense of one's practice, experiences, or actions.

- Practice: mutual engagement in action supported by the resources and work contexts. The construction of meaning related to experience is possible through practice.

- Community: a group of individuals who focus on achieving projects. Based on mutual commitment, interpersonal relationship building, and belonging to a group.

- Identity: impact of the learning experience on the participant. Knowledge is transformed in a learning process that contributes to building a person's identity through the CoP.

\section{Materials and Methods}

\subsection{Participant Recruitment}

The data in this study were taken from a Social Sciences and Humanities Research Council (SSHRC-Canada) project (Professional Learning Community for School Improvement) led by author. To recruit participants, the author asked for the collaboration of the Association Québécoise du Personnel de Direction des Écoles (AQPDE) which passed on the information associated with the project to its members. Projects were looking for school principals or assistant principals 
currently in office and interested in sharing their practices with their peers in virtual mode over a two-year period. Interested school principals registered directly with the head of research.

\subsection{Participants}

Six school principals (PR) and four vice-principals (VPR) $(\mathrm{N}=10)$ participated in this study. These people did not know each other before this project. Half were employed in primary schools (3PR and 2 VPR) and half worked in secondary schools (3PR and 2 VPR). Eight participants were women and two were men from different school districts in the province of Québec, Canada. They came from different regions (Iles de la Madeleine, Québec, Lévis, Beauce, Montréal and Abitibi). The schools from which these principals came varied as much in terms of student numbers as of demographic context. The number of years of school management experience ranged from a few months to 10 years. On average, participants had six years of experience in school management.

\subsection{Data Collection and Analysis}

Participants met eight times during the 2018-2019 school year. The first meeting consisted of a half-day face-to-face meeting, followed by seven 90-minute virtual sessions. At the end of the first year, each participant was interviewed for their views on their COP experience. Specifically, interviews of approximately $60 \mathrm{mi}-$ nutes each allowed participants to explain how their participation in the CoP has contributed to their professional development by providing examples of new practices incorporated into their management.

The transcribed interviews underwent thematic analysis following the three steps method of Paillé \& Mucchielli (2003): identification, grouping, and discursive examination of the themes addressed in a corpus. We used QDA Miner qualitative data analysis software and a coding list based on our conceptual framework. We categorized the data especially on the aspects of the learning experienced in the CoP (Wenger, 2005), namely, meaning, practice, community, and identity.

In order to eliminate any possible biases in qualitative research, intra-coder and inter-coder verification has been used. Intra-coder reliability (conducted in a two-week interval) revealed a $94 \%$ correlation between the two codings, while inter-coder reliability (the same work performed by a second independent coder) showed a $92 \%$ agreement and was within the standards set by Huberman and Miles (2003).

\section{Results}

The most significant characteristics of the virtual CoP are evidenced within the data gathered from the transcribed verbatims, for which the four learning theory assumptions (Wenger, 2005) were used as the coding list.

\subsection{Learning as Meaning}

The first element of learning (Wenger, 2005) regards the attribution of meaning 
to experiences or to actions. It translates here to giving meaning to a practice.

\section{Sharing Experiences in Virtual Mode}

Discussions with their peers enabled the participants to find meaning in their respective actions, as is shown in the following excerpt by one principal who expressed how they experienced this activity:

At the same time, I would say that it confirms that what I am doing, it's validated a bit by the fact that others basically do the same thing that I do and that what I hear makes me continue in the right direction; it validates me. (PR03)

Sharing practices with their colleagues made it possible to identify winning practices: ... from the others' experience, then sharing what works in our school (VPR05) as well as less effective ones. Another participant explained that the CoP had helped them to review certain older practices and even rate their level of effectiveness: ... It's also sharing the good practices but also the challenges we face; some said that if we had to do it over, we would not do that one again (VPR04). Another participant stated that the CoP had propelled them to eventually try certain practices in their school:

Of course, the experience shared by the other principals was invaluable to me because it gave me a lot of ideas and inspired me tremendously. [... ...To see how, what they know, how they did it, their successful actions and the difficulties they faced. (VPR04)

These sharing activities were thus food for thought as they inspired their own future actions in their school: There were some very interesting things that we could adopt, which I greatly appreciated (PR01).

Learning about what was being done in the other schools enabled the participating principals and vice-principals to put their own practices into perspective compared to those of the other CoP members and ultimately contribute to creative problem solving:

It allowed me to hear about things that went on elsewhere, to learn about what they were doing. It helped me to look for solutions, so it's really at that level that it was highly rewarding for me. (VPR03)

For this vice-principal, the discussions and dialogues with their colleagues were what helped this person reflect on their practice in regards to those of other members: ... to validate or invalidate my knowledge and sometimes to learn about the reality of my colleagues (VPR02).

\subsection{Learning as Practice}

This second learning component (Wenger, 2005) pertains to the practice which is defined as the mutual commitment in action supported by work-relevant resources and contexts. The construction of meaning related to experience is possible through practice. This component houses two sub-themes, namely, 1) 
participant heterogeneity and 2) the role of the facilitator.

\subsubsection{Participant Heterogeneity}

Because the group was heterogeneous in terms of years of school management experience, some members understandably had more to share than others did; however, each participant was able to have their say at their own pace: Then there were times when I could also discuss and share things (VPR05). Another vice-principal who admitted having initially doubted her expertise was able to contribute several times by sharing her experience: In the end, I felt that my expertise was somehow appreciated on several occasions, so I was able to share, which I liked a lot (VPR02).

Finally, this diversity was also evident in the geographical sense, as mentioned by one vice-principal who viewed the virtual CoP project as an opportunity to bring together participants from different areas: The geographical difference adds colour, which can be highly visual from one person to another, depending on their organisation (VPR02).

Indeed, the virtual-mode CoP enabled school leaders from remote regions to join a common sharing platform: It made it possible for me to talk with other people because we were in fact principals from all over Québec; it was truly wonderful, I really appreciated it (VPR03). Those who would have preferred participating in a CoP in person nevertheless understood that it would have been difficult for certain members of the group: For me, it doesn't help discussion; it's easier in person. But I do think that it's highly useful to those who live far away (PR02). Another participant referred to the same thing: I think it can be helpful for those who are far away and who want to participate (VPR04).

\subsubsection{The Role of the Facilitator}

The facilitator's role should be strategic by creating openings for discussions between the CoP members and going beyond simply listening. One participant stated:

Because Mr. (...) was the facilitator at each CoP meeting, we were more passive; otherwise, it might have been possible to participate more actively. (VPR02)

This vice-principal explained that the level of participation during the CoP meetings differed from one person to the next, which was why having a facilitator was important to involve each member of the group, depending on their experience:

...by explaining the expectations to each CoP member or from now to the next meeting, we expected that that person or this one would present this or that part... It would have been good to see all of the members participating in the CoP, I mean actively participate, but obviously some people were neophytes and there was a huge diversity in terms of knowledge among the CoP members. (VPR02) 


\subsection{Learning as Community}

The individuals who participate as a group to undertake a project, namely, the community, represents the third element in the learning theory (Wenger, 2005). This includes the members' mutual commitment, their interactions, and their sense of belonging to the group. Two sub-themes are highlighted in this third theme: 1) the relational aspect and 2) the commitment.

\subsubsection{The Relational Aspect in the Virtual Group}

For the CoP to be successful, each member must completely invest in the process, interact with the other members, and build rich interpersonal relationships to consolidate their sense of belonging to the group, as underlined by this participant:

What I found hard was that I found the others to be a bit, well, closed off to the idea of talking. Often, it was hard to grasp what they were doing; I noticed that it was often the same three, four people in the discussion. (PR01)

The virtual distance between the participants was difficult for some participants who wondered how their words were being interpreted: I didn't say much; I didn't ask too many questions because then... how would it come off? (PR04). Another participant stated: It's not a formula where we really dig deep into feelings (PR03). However, when mentioning these challenges, the participants did acknowledge the fact that CoPs need time to reach cruising speed: Maybe there will be more in Year 2, and of course, we are all probably at different levels in terms of our competence or knowledge (PR01).

\subsubsection{Commitment in the Virtual CoP}

Because the participants had similar occupations, namely, that of school leader, they all had something in common which they could share: If everyone does the same thing, sharing this can obviously create a chemistry; it's also more on the level of commitment (VPR04). There appeared to be a difference in the level of engagement of these $\mathrm{CoP}$ members, as mentioned by this participant: I found that it was always the same ones who spoke; some were absent (PR01).

This principal mentioned the difficulty trying to sense how the person they were virtually interacting with perceived what they were saying: But we didn't feel the pulse of the meeting; we could see everyone sitting at their desk (PR01). Those who shared their experiences questioned the quality and quantity of their input and how the others interpreted what was shared: But what was hard for me was that at a certain point, I thought to myself: Am I talking too much? Are they interested in what I am saying? That type of thing (PR01).

Finally, one participant hoped that a second year of CoP sessions with the same members would strengthen their interactions and communication: Maybe if we go another year, we could push it a bit further (VPR04).

\subsection{Learning as Identity}

Identity, the fourth learning theory component (Wenger, 2005), regards the im- 
pact the learning experience has on the individual. A learning process necessarily involves a transformation of knowledge, which contributes to the construction of that person's identity. Their personal identity as well as their professional identity will be developed along with that of the community in which the person evolves through the activities proposed in the CoP.

\section{Personal and Professional Identity}

The CoP experience is expected to have an impact on its members through the sharing of practices during the meetings. As mentioned by one participant: I listened to learn about what was being done elsewhere and we looked at these practices (PR04).

According to another participant, the positive effect of the CoP on learning was felt through the sense of belonging to the group, which was even more sensitive in virtual mode, as the members were less inclined to share because they knew each other less than in a close-proximity CoP:

Due to the distance, going deep into issues to try to go forward, to develop our practices, our strategies, etc., you definitely have to have developed a sense of belonging, of community, of mutual trust. (PR04)

\section{Discussion}

The goal of this study was to examine how a virtual-mode CoP can develop the professional competence of school principals. The analysed corpus, following Wenger's (2005) four themes associated with learning (meaning, practice, community, and identity), enabled us to identify the main facets of the virtual CoP work approach. In its first year of operation, the first two themes, namely, meaning and practice, progressed more compared to community and identity.

\subsection{Learning as Meaning}

\section{Sharing Experiences in Virtual Mode}

Our analysis of the principals' responses indicates that they indeed benefited from the knowledge and experience of their peers in the $\mathrm{CoP}$ and thus gave meaning to their actions, to which Wenger et al. (2002) alluded: "By spending time together, they share information, ideas, and advice. They help each other solve problems. They discuss their situation, their aspirations, and their needs." (p. 4). For some members, this exchange of knowledge and their growth in this area added to their professional competence, whereas for others, it generated new ideas for them to apply in their respective institutions.

This first year of operation as a virtual CoP also enabled the principals to share expertise. This is supported by McDermott (2001) who noted that in CoPs, certain members are more active than others. In our study, the participants' work experience in school management ranged from a few months to 10 years; newcomers were thus able to benefit from the ideas, methods, and knowledge of the more seasoned veterans to support their learning and growth in the area of school management through the virtual CoP's activities. 
The principals and vice-principals were able to discuss and share their concerns and practices, which was indubitably beneficial to their learning as well as their problem-solving skills with the help of their colleagues' knowledge and experience (Snyder \& Wenger, 2000). The CoP thus made it possible for its members to compare and study their respective practices and to identify which ones were the most effective. Wenger (2005) speaks of a negotiated meaning to interpret experiences or actions and that this search for meaning requires open communication between the members. In our interview analyses, we found that the virtual discussions between the participants allowed for the attribution of meaning to their shared experiences.

That said, CoP members may need to share problems, experiences, models, tools, and effective practices between two meetings, which is why calling upon a colleague is more encouraged than are consulting the literature or going on line (Meagher-Stewart, Solberg, Warner, MacDonald, McPherson, \& Seaman, 2012; Kothari, Rudman, Dobbins, Rouse, Sibbald, \& Edwards, 2012). Interactions between CoP members must therefore be encouraged between meetings by using, for example, the technology already set up in the virtual $\mathrm{CoP}$ to maintain contact with the others to further discuss issues or for mutual support. This, according to Wenger (2005), helps strengthen the sense of community within the group.

\subsection{Learning as Practice}

\subsubsection{Participant Heterogeneity}

According to Wenger et al. (2002), creativity is enhanced in CoPs where there is diversity, as evidenced in the virtual CoP analysed here, with the relevant work experience ranging from a few months to 10 years. Several authors (Mitchell, 2002; Snyder \& Wenger, 2000; Wenger, 1998; Wenger et al., 2002) also found heterogeneity to be advantageous in a $\mathrm{CoP}$, as this work model enables recruits to benefit from the expertise of veteran school leaders who in turn contribute to the collective actions by sharing their knowledge.

Diversity was also present in terms of instruction levels (principals from both primary and secondary institutions) as well as in the economic and geographical contexts of the respective schools. The sum of these factors ultimately enriched the CoP members' discussions regarding their respective practices because they were varied and helped them explore new pedagogical avenues (Wenger, 1998).

\subsubsection{The Role of the Facilitator}

The role of the CoP facilitator is to help establish an effective work process (Wenger et al., 2002). Some of our participants mentioned that they would have appreciated receiving clearer indications as to how the CoP would proceed, particularly in light of the virtual nature of this initiative, which was more demanding in terms of interactions between the members.

Listening in a virtual CoP continues to be a major challenge (Wenger, 2001), as the motivation and interest of the members depend to a certain extent on the energy level of the facilitator who is there to encourage and support the PD of 
the CoP members (Tremblay, 2004). You cannot coerce members into participating (Wenger et al., 2002); to overcome the virtual barrier, the situation calls for careful planning by the facilitator so that every member of the group feels comfortable. The facilitator is responsible for nurturing the group's dynamics and supporting fruitful discussion.

\subsection{Learning as Community}

\subsubsection{The Relational Aspect in the Virtual Group}

After one year of operation, having good relationships in the virtual CoP is crucial to building a lasting climate of mutual respect and trust that will inevitably influence the course of the discussions and the sharing. Wenger et al. (2002) abounded along the same lines: "They also develop a personal relationship and find ways to share with the others. They can also develop a collective identity: They become a community of practice." (p. 5).

During the course of this first year of operation, the participating principals and vice-principals got to know each other, despite the physical distance and the virtual setting which did slow the theme of community (Wenger, 2005) in terms of the relational aspects within the group. Now, for the CoP to continue, its members must trust each other enough to delve beyond the superficial conversations regarding their day-to-day concerns. It goes without saying that some participants created meaningful and trusting relationships with other members more rapidly than did other members, as stated during the interviews. Cohesion therefore remains crucial to the success of the CoP; the fact that the participants in the virtual CoP expressed their desire to pursue their group's activities for a second year will enhance the sense of community in this learning process (Wenger, 2005).

\subsubsection{Commitment in the Virtual CoP}

Following an initial in-person meeting, the participating principals and vice-principals committed to the seven virtual sessions that followed. For Wenger (2005), this represents one of the guiding motors of the CoP, as without commitment, it cannot reach sustainment and fruition. While mutual engagement is a key factor in successful CoPs (Wenger, 1998), it does not come automatically, as we learned from the participants' interviews. CoP members must undoubtedly work together to create a sense of belonging, which in the case of virtual activities can be challenging. In this case, certain ice-breaking actions at the beginning of each meeting could be added to enable the members to learn more about their colleagues and develop ties that will be useful in the sessions to come. As regards our virtual $\mathrm{CoP}$, having launched this group with a face-to-face initiatory meeting was an excellent action as it served to introduce the knowledge level and expertise of each member and to get a sense of each person prior to the virtual sessions.

When a group is fully invested in the process, a sense of belonging is created and makes learning possible (Wenger et al., 2002), which is capital in the CoP 
model which drives the sharing of experiences and expertise. With a small group of participants, cohesion is more readily achieved, as suggested by Wenger (2005) who recommended a limited number of participants when implementing a CoP.

It takes a certain amount of time before the members of a CoP can fully understand the importance of their contribution (Wenger et al., 2002). Indeed, as Wenger (2005) put it: "The task of 'maintaining the community' is a basic dimension of any practice, but it often goes unnoticed and can be easily underestimated or even ignored" (p. 84). In the virtual CoP analysed in this study, the fact that the members expressed their intention to pursue the $\mathrm{CoP}$ experience for another year suggests that the time spent together will nurture deeper interactions which in turn will enhance their commitment to continue their professional growth by sharing winning practices, common educational challenges, or issues for more profound discussions and creative problem solving. On the basis of the participants' responses during the interviews, their desire for community shows promise.

\subsection{Learning as Identity}

\section{Personal and Professional Identity}

The virtual CoP activities made it possible for each member to grow, both professionally and personally, which as a result had a positive impact on their identity. Following their experience in the CoP, the level of introspection varied from one participant to the next. As we observed in our analysis, the gains were not completely understood by everyone; however, their decision to pursue the CoP for a second year will no doubt heighten their awareness of the strides they have made regarding their personal and professional identity.

During the interviews, the participants who spoke often of their progress were those with the least amount of school management experience. The level of experience among the participating principals varied, from a few months to 10 years, which confirms that this virtual CoP was composed of both novices and seasoned veterans in this domain. Therefore, the more experienced principals could expound certain themes, as they knew more about their roles and responsibilities, compared to the newcomers (Tremblay, 2004). As a result, younger principals and particularly novice vice-principals were able to benefit from the experience and knowledge of their veteran colleagues, acquire certain key professional skills, and gain in confidence to transform this new knowledge into effective actions in their own practices (Gherardi \& Nicolini 2002), which ultimately strengthened their identity. Moreover, one of our participants who was new to the profession explained that he was able to join the conversation despite his lack of experience, demonstrating that newcomers can successfully integrate and actively participate in the CoP's activities (Lave \& Wenger, 1991). It is therefore important that the environment created for the $\mathrm{CoP}$ and the available resources be there to foster the development of each member of this community, at their own pace and professional orientation, to help forge and support their 
identity.

\subsection{Main Characteristics of the Virtual CoP after One Year of Operation}

The different elements of learning inspired by Wenger (2005) were evidenced on various levels in the virtual CoP under study, thus confirming that this experience ensured the PD of each participant.

Among the benefits enumerated by the participants after one year as a virtual CoP, we observed that meaning (Wenger, 2005), through the sharing of their experiences to enhance their learning, was greatly appreciated by the participating principals and vice-principals. We gathered from the comments that the discussions greatly facilitated the exchange of knowledge on their common issues and helped them reflect on their different professional practices. Each participant evolved at their own pace and learned from their CoP colleagues' expertise, which created opportunities to try new practices and strategies. Therefore, the meaning associated with the practice (Wenger, 2005) was enormously beneficial during the first year of the virtual CoP.

Furthermore, all of the participants agreed that the advantages of being a heterogeneous CoP far outweighed the disadvantages. They discovered that having this heterogeneity can actually enrich the process and that different experiences, geographical origins, or levels of experience can in fact be assets in a CoP.

In the early 2000s, as the CoP model began exploring technological support tools, Wenger's (2001) work revealed the benefits of using technology in this continuing development setting, such as the possibility of recruiting participants over a larger territory or the working with socially recognised technological tools, among others. In the eyes of the participants, the fact of having a CoP in virtual mode added value to the more traditional format. However, some concerns were raised, such as the idea of belonging to a group that only meets in virtual mode. The virtual CoP must therefore prioritise cohesion between its members and the sense of belonging. As was highlighted in some participant interviews, although the CoP's virtual format did not easily facilitate commitment, a number of participants believed that it was an attainable goal over time.

Therefore, because this virtual CoP involved a small number of participants who all had school management experience, because feedback was given after each meeting (which notably made it possible to adjust the technology), and because distance and technology did not discourage the participants invested in the process, the group possesses the winning conditions to ensure its long-term sustainment for the benefit of all concerned.

Finally, we must specify that for a first year in this new CoP, one of the objectives was to create a strong community among the participants in order to ensure a sense of belonging, especially since they did not know each other at the beginning and we were using technology to communicate, which could be a barrier to sharing. To do this, it was decided at first to focus the meetings by having the school principals share their experiences and how they reacted to them, so 
that they could give meaning to their practices and try new ones which could be shared in subsequent meetings. We believe that we have succeeded in this first step as participants will continue their participation in the CoP for a second year. During these future meetings, the continuation of the CoP in professional development of school principals will be based mainly on the actions requested from the competency framework for school management by the Ministère de l'éducation from Québec (MELS, 2008). This second stage will thus allow each participant to go further in terms of professional development in their function by benefiting from the sharing between colleagues to advance, each at their own pace, taking into account the competencies expected by the Ministère de l'éducation for the school principals (MELS, 2008).

\section{Conclusion}

According to Wenger (2005), the CoP requires that its members experience different phases of growth. In the case of the virtual CoP analysed here, it was in its early stage, that of having potential, when its members discovered and got to know each other and expressed their interest in the proposed activities. After one year of virtual CoP sessions, when asked whether they wanted to continue for another year, seven of the 10 participants chose to do so, attesting that they had grown professionally during this first year and were looking forward to expanding their professional development the following year.

The CoP in virtual mode therefore contributes to the professional development of school leaders. The structured networking within a $\mathrm{CoP}$ has allowed each of the school principals to give and receive in a collaborative sharing aimed at improving the professional competencies needed to fulfill their roles and responsibilities effectively, each at his or her own pace. This virtual CoP allowed for sharing among participants from different regions of the province. This sharing was much more important since school principals usually gather specifically with colleagues from their own service centers. The exchanges were more diversified. Furthermore, there is a future for this type of collaborative platform as an effective tool to consolidate knowledge, according to the themes laid forth by Wenger (2005). That said, reaping the tangible benefits does take time. The interviews we conducted lead us to confirm that certain conditions must be in place for a virtual CoP to be successful. And while commitment to the process and the sense of belonging to the group are slower to cultivate in the virtual CoP, it nevertheless provides excellent opportunities for collaborations between members despite the physical distancing, which today no longer represents a barrier.

The CoP concept is grounded in the sharing of both experiences and information among a limited number of members, which fosters greater cohesion (Wenger, 2005). Despite a few challenges during its implementation, these school leaders recognised that joining and belonging to a group of peers was an excellent opportunity for growth, which they took to heart. 


\section{Acknowledgements}

This work was supported by the Social Sciences and Humanities Research Council of Canada (Grant no. 435-2018-0716).

\section{Conflicts of Interest}

The authors declare no conflicts of interest regarding the publication of this paper.

\section{References}

Barber, M., Whelan, F., \& Clark, M. (2010). Capturing the Leadership Premium. How the World's Top School Systems Are Building Leadership Capacity for the Future. London: McKinsey \& Company.

Barbier, J. M., \& Galatanu, O. (2004). Les savoirs d'action: Une mise en mot des compétences? Paris: L'Harmattan.

Beckers, J. (2010). Formation initiale et développement professionnel des enseignants: quel rôle de l'évaluation? In L. Paquay, C. Nieuwenhoven, \& P. Wouters (Eds.), L'évaluation, levier du développement professionnel? (pp. 147-160). Bruxelles: De Boeck.

Bisaillon, R., Inchauspé, P., Massé, D., Miron, D., Morin, S., \& Sauvageau, P. (2009). Un collectif pour l'éducation; l'école comme établissement d'enseignement et la réussite. De l'accessibilité à l'école à la réussite dans l'école. FQDE.

Bourdoncle, R. (1991). La professionnalisation des enseignants: Analyses sociologiques anglaises et américaines. Revue Française de Pédagogie, 94, 73-91.

https://doi.org/10.3406/rfp.1991.1368

Brodeur, M., Deaudelin, C., \& Bru, M. (2005). Introduction: Le développement professionnel des enseignants: Apprendre à enseigner pour soutenir l'apprentissage des élèves. Revue des Sciences de l'Éducation, 31, 5-14. https://doi.org/10.7202/012355ar

Cattonar, B., Lessard, C., Blais, J.-G., Larose, F., Riopel, M. C., Tardif, M., \& Bourque, J. (2007). Les directeurs et les directrices d'école au Canada: contexte, profil et travail. Enquêtes pancanadiennes auprès des directions et des enseignants d'écoles primaires et secondaires (2005-2006). Rapport de recherché, Québec, Canada: Statistique Canada.

CTREQ (Centre de transfert pour la réussite éducative du Québec) (2013). Innover dans les modalités du Développement professionnel.

https://www.ctreq.qc.ca/innover-les-modalites-du-developpement-professionnel/

Coombs, P. H., Prosser, R. C., \& Ahmed, M. (1973). New Paths to Learning for Rural Children and Youth. New York: International Council for Educational Development.

Daele, A. (2004). Développement professionnel des enseignants dans un contexte de participation à une communauté virtuelle: Une étude exploratoire. Unpublished report for DEA in Educational Sciences, Louvain-la-Neuve: Université Catholique de Louvain.

Darling-Hammond, L., Meyerson, D., LaPointe, M., \& Orr, M. T. (2010). Preparing Principals for Changing World. San Francisco, CA: Josey-Bass.

Davis, S., Darling-Hammond, L., LaPointe, M., \& Meyerson, D. (2005). Review of Research, School Leadership Study: Developing Successful Principals, Palo Alto, CA: Stanford Educational Leadership Institute, Wallace Foundation.

Day, C. (1999). Developing Teachers. The Challenges of Lifelong Learning. London: The Falmer Press.

Gherardi, S., \& Nicolini, D. (2002). Learning in a Constellation of Interconnected Prac- 
tices: Canon or Dissonance? Journal of Management Studies, 39, 419-436. https://doi.org/10.1111/1467-6486.t01-1-00298

Guillemette, S., \& Savoie-Zajc, L. (2012). La recherche-action et ses rapports de co-construction de savoirs et de formation dans une perspective de professionnalisation entre acteurs praticiens et chercheurs. Formation et Profession, 20, 41-52.

Huberman, A. M., \& Miles, M. A. (2003). Analyse des données qualitatives. Bruxelles, Belgique: Éditions de Boeck.

Ingvarson, L., Anderson, M., Gronn, P., \& Jackson, A. (2006). Standards for School Leadership: A Critical Review of Literature. Acton, Australia: Australian Institute for Teaching and School Leadership.

Isabelle, C., \& Labelle, J (2017). Rôles, responsabilités, pratiques et compétences des directions d'école. Revue des Sciences de l'Éducation, 43, 1-14. https://doi.org/10.7202/1043024ar

Isabelle, C., Meunier, H., \& Gélinas Proulx, A. (2016). Contextes de formation des nouvelles directions d'écoles au Canada. McGill Journal of Education, 51, 877-898. https://doi.org/10.7202/1038607ar

Kothari, A., Rudman, D., Dobbins, M., Rouse, M., Sibbald, S., \& Edwards, N. (2012). The Use of Tacit and Explicit Knowledge in Public Health: A Qualitative Study. Implementation Science, 7, 7-20. https://doi.org/10.1186/1748-5908-7-20

L'Hostie, M., \& Boucher, L. P. (2004). L'accompagnement en education: Un soutien au renouvellement des pratiques. Québec: Presses de l'Université du Québec.

https://doi.org/10.2307/j.ctv18ph4nc

Lave, J., \& Wenger, E. (1991). Situated Learning: Legitimate Peripheral Participation. Cambridge, MA: Cambridge University Press. https://doi.org/10.1017/CBO9780511815355

Le Boterf, G. (2007). Professionnaliser; Le modèle de la navigation professionnelle. Paris: Éditions d'Organisation.

Le Boterf, G. (2008). Repenser la compétence. Paris: Éditions d’Organisation.

Legendre, M.-F. (2007). Conclusion. In L. Bélair, D. Laveault, \& C. Lebel, C. (Dir.), Les compétences professionnelles en enseignement et leur évaluation (pp. 229-248). Ottawa, Canada: Presses de l'Université d'Ottawa. https://doi.org/10.2307/j.ctt1cn6tf9.21

Lesser, L., \& Storck, J. (2001). Communities of Practice and Organizational Performance. IBM Systems Journal, 40, 831-841. https://doi.org/10.1147/sj.404.0831

Lieberman, A., \& Miller, L. (2001). Teachers Caught in the Action. Professional Development that Matters. New York: Teachers College Press.

McDermott, R. (2001). Knowing in Community: 10 Critical Success Factors in Building Communities of Practice.

Meagher-Stewart, D., Solberg, S. M., Warner, G., MacDonald, J.-A., McPherson, C., \& Seaman, P. (2012). Understanding the Role of Communities of Practice in Evidence-Informed Decision Making in Public Health. Qualitative Health Research, 22, 723-739. https://doi.org/10.1177/1049732312438967

MELS, Ministère de l'Éducation, du Loisir et du Sport (2008). La formation à la gestion d'un établissement scolaire: Les orientations et les compétences professionnelles. Gouvernement du Québec.

Merriam, S. B., Caffarella, R. S., \& Baumgartner, L. M. (2009). Learning in Adulthood: A Comprehensive Guide (3rd ed.). San Francisco, CA: Jossey-Bass.

Mitchell, J. (2002). The Potential for Communities of Practice to Underpin the National 
Training Framework. Melbourne: Australian National Training Authority.

Mottier-Lopez, L. (2007). L'impact des communautés de pratique dans les entretien $s$ de co évaluations. In A. Jorra, Évaluation et développement professionnel (pp. 153-168). Paris: L'Harmattan.

Mulford, B. (2003). L'évolution des fonctions de directions en milieu scolaire et son incidence sur l'efficacité des enseignants et des établissements. OCDE.

Murakami, E. T., Tornsen, M., \& Pollock, K. E. (2014). School Principal' Standards and Expectations in Three Educational Contexts. Canadian and International Education/Education Canadienne et Internationale, 43, Article 7. https://doi.org/10.5206/cie-eci.v43i1.9242

Nolan, J. F., \& Hoover, L. A. (2008). Teacher Supervision and Evaluation: Theory into Practice (2nd ed.). New York: Wiley and Sons.

NPBEA, National Policy Board for Educational Administration (2015). Professional Standards for Educational Leaders 2015. Reston, VA: NPBEA.

OCDE (2007). Qualifications Systems: Bridges to Lifelong Learning. http://www.oecd.org/education/country-studies/38465471.pdf

Paillé, P., \& Mucchielli, A. (2003). L'analyse qualitative en sciences humaines et sociales. Paris, France: Armand Colin.

Paquay, L., Nieuwenhoven, C., \& Wouters, P. (2010). L'évaluation, levier du développement professionnel? Bruxelles, Belgique: De Boeck.

Payette, A., \& Champagne, C. (1997). Le groupe de co-développement professionnel. St-Nicolas, QC: Les presses de l'Université du Québec.

Perrenoud, P. (2002). Une formation réflexive et constructiviste des chefs d'établissement. https://www.unige.ch/fapse/SSE/teachers/perrenoud/php_main/php_2002/2002_11.ht $\underline{\mathrm{ml}}$

Pont, B., Nusche, N., \& Moorman, H. (2008). Améliorer la direction des établissements scolaires. Volume 1: Politiques et pratiques. OCDE.

Richter, D., Kunter, M., Klusmann, U., Lüdtke O., \& Baumert, J. (2011). Professional Development across the Teaching Career: Teachers' Uptake of Formal and Informal Learning Opportunities. Teaching and Teacher Education, 27, 116-126. https://doi.org/10.1016/j.tate.2010.07.008

Salazar, P. S. (2007). The Professional Development Needs of Rural High School Principals: A Seven-State Study. The Rural Educator, 28, 20-27. https://doi.org/10.35608/ruraled.v28i3.475

Savoie-Zajc, L. (2010). Les dynamiques d'accompagnement dans les communautés d'apprentissage. Éducation et Formation, 293, 9-20.

Snyder, W. M., \& Wenger, E. (2000). Cultiver vos réseaux invisibles. L'Expansion Management Review, No. 96, 6-12.

Tremblay, D. G. (2004). Communities of Practice: Are the Conditions for Implementation the Same for a Virtual Multi-Organization Community? Chaire de recherche du Canada sur les enjeux socio-organisationnels de l'économie, Montréal: Télé-Université.

UNESCO (2006). Les nouveaux rôles des chefs d'établissement dans l'enseignement secondaire. Paris, France: Organisation des Nations Unies pour l'éducation, la science et la culture.

Uwamariya, A., \& Mukamurera, J. (2005). Le concept de "développement professionnel" enseignement: approches théoriques. Revue des Sciences de l'Éducation, 31, 133-155.

https://doi.org/10.7202/012361ar 
Wenger, E. (1998). Communities of Practice: Learning, Meaning and Identity. New York: Cambridge University Press. https://doi.org/10.1017/CBO9780511803932

Wenger, E. (2001). Supporting Communities of Practice: A Survey of Community Oriented Technologies. How to Make Sense of the Emerging Market Understand the Potential of Technology and Set up a Community Platform.

Wenger, E. (2005). La théorie des communautés de pratique: Apprentissage, sens et identité. St-Nicolas, QC: Les presses de l'Université Laval.

Wenger, E., McDermott, R., \& Snyder, W. M. (2002). Cultivating Communities of Practice: A Guide to Managing Knowledge. Boston, MA: Harvard Business School Press.

Werquin, P. (2010). Reconnaître l'apprentissage non formel et informel. Résultats, Politiques et Pratiques (rapport). Paris, France: Éditions OCDE.

http://www.cicic.ca/docs/oecd/rnfil.fr.pdf

Wittorski, R. (2007). Professionnalisation et développement professionnel. Paris: L'Harmattan. 